\title{
GAMBARAN PERUBAHAN TEKANAN DARAH PADA LANSIA HIPERTENSI YANG MELAKUKAN SENAM LANSIA
}

\author{
Arif Mulyadi $^{1}$, Tri Cahyo Sepdianto ${ }^{2}$, Dwi Hernanto ${ }^{3}$ \\ 1,2,3 Poltekkes Kemenkes Malang Jurusan Keperawatan \\ Email: arif.mly@gmail.com
}

\begin{abstract}
Abstrak
Hipertensi merupakan risiko utama pada lansia untuk terjadinya stroke, gagal jantung dan penyakit koroner, peranannya lebih besar dibandingkan usia muda. Senam lansia merupakan olahraga untuk meningkatkan kelenturan badan dan kontraksi otot-otot badan, sehingga dapat menurunkan tekanan darah. Tujuan penelitian ini adalah untuk mendeskripsikan perubahan tekanan darah pada lansia hipertensi yang melakukan senam lansia. Desain penelitian ini adalah deskriptif dengan pendekatan studi kasus. Subyek pada penelitian ini adalah lansia di UPT Puskesmas Ngantang Kabupaten Malang berjumlah 20 orang. Pengumpulan data menggunakan observasi, wawancara dan dokumentasi. Data hasil penelitian disajikan dalam bentuk grafik dan narasi. Hasil penelitian menunjukkan bahwa sebelum melakukan senam lansia 11 orang $(55 \%)$ mengalami hipertensi derajat 1 , dan hipertensi derajat 2 sebanyak 9 orang (45\%). Tekanan darah pasien sesudah melakukan senam lansia menunjukkan penurunan pada sebagian besar pasien yaitu sebanyak 18 orang (90\%), sedangkan sisanya 1 orang $(5 \%)$ naik dan 1 orang $(5 \%)$ tetap. Rekomendasi kepada lansia yang menderita hipertensi untuk melakukan senam lansia karena dapat menurunkan tekanan darah.
\end{abstract}

Kata Kunci: Lansia, Senam, Tekanan Darah

\begin{abstract}
Description of Changes in Blood Pressure in Elderly Hypertension in Elderly Gymnastics. Hypertension is a major risk of elderly for stroke, heart failure and coronary disease, its role is greater than young age. Elderly gymnastics is a sport to increase body flexibility and contraction of body muscles, so that it can lower blood pressure. The purpose of this study was to describe changes in blood pressure in elderly hypertension who performed elderly gymnastics. The design of this study is descriptive with a case study approach. The subjects in this study were 20 elderly patients in the Ngantang Public Health Center Malang Regency. Data collection uses observation, interviews and documentation. Data results are presented in graphical and narrative form. The results showed that before doing elderly exercise most subjects had grade 1 hypertension as many as 11 subjects (55\%), and grade 2 hypertension as many as 9 subjects (45\%). Subject blood pressure after performing elderly gymnastics showed that most subjects had a drop in blood pressure of 18 subjects (90\%), an increase of 1 subject $(5 \%)$ and blood pressure remained 1 subject (5\%). Recommendation for elderly people who suffer from hypertension to do elderly exercise because it can lower blood pressure.
\end{abstract}

Keywords: Elderly, Gymnastics, Blood Pressure

\section{Pendahuluan}

Keberadaan lansia yang semakin kemunduran sel-sel yang dapat mempengaruhi fungsi dan kemampuan meningkat menimbulkan berbagai polemik dewasa ini, berbagai masalah fisik, psikologis dan sosial akibat proses degeneratif yang muncul seiring dengan menuanya seseorang. Pada lansia terjadi sistem tubuh seperti sistem syaraf, jantung, dan pembuluh darah. Penyakit lansia yang mempunyai tingkat morbiditas dan mortalitas tinggi yaitu hipertensi (Darmojo, 2012). Hipertensi merupakan tekanan darah 
persisten dengan tekanan sistoliknya di atas $140 \mathrm{mmHg}$ dan diastolik di atas $90 \mathrm{mmHg}$, sedangkan pada populasi lansia tekanan sistolik $160 \mathrm{mmHg}$ dan diastolik $90 \mathrm{mmHg}$ (Murwani, 2014). Hipertensi lansia sebagian besar hipertensi sistolik terisolasi, yaitu meningkatnya tekanan sistolik menyebabkan timbulnya kejadian stroke, walaupun diastoliknya normal. Hipertensi merupakan risiko utama untuk stroke, gagal jantung dan penyakit koroner, peranannya lebih besar dibandingkan usiamuda (Kuswardhani, 2011).

Di Indonesia prevalensi hipertensi pada lansia dari hasil Riskesdas tahun 2013 menunjukkan cukup tinggi yaitu 45,9\% pada kelompok umur 55-64 tahun, 57,6\% pada umur 65-74 tahun dan 63,8\% pada kelompok umur 75 tahun ke atas (Kemenkes R1, 2016). Di Jawa Timur pada tahun 2015, persentase hipertensi sebesar $13,47 \%$ atausekitar 935.736 penduduk, dengan proporsi lakilaki sebesar 13,78\% (387.913penduduk) dan perempuan sebesar $13.25 \% \quad(547.823$ penduduk). Di Kabupaten Malang tahun 2015 persentase hipertensi 7,32\% atau 21564 penduduk dengan proporsi laki-laki 6,81\% dan perempuan 7,78\% (Dinkes Jatim, 2016). Sementara itu berdasarkan laporan Puskesmas Ngantang tercatat pasien yang menderita hipertensi sepanjang tahun 2014 berjumlah 644 kasus dan dari jumlah tersebut sebesar 450 kasus (70\%) pasien hipertensi adalah lansia.

Hipertensi merupakan masalah yang ditemukan terbukti meningkatnya morbiditas dan mortalitas serta mengurangi kualitas hidup terutama pada lansia. Penyebab hipertensi pada lanjut usia dikarenakan terjadinya perubahanperubahan pada elastisitas dinding aorta menurun, katup jantung menebal dan menjadi kaku, kemampuan jantung memompa darah menurun, sehingga kontraksi dan volumenya pun ikut menurun, kehilangan elastisitas pembuluh darah karena kurang efektifitas pembuluh darah perifer untuk oksigen, meningkatnya resistensi pembuluh darah perifer. Selain itu seperti konsumsi garam tinggi, obesitas, kolesterol tinggiapat membuat pembuluh darah menyempit dan akibatnya tekanan darah akan meningkat. Stres, kondisi emosi yang tidak stabil, merokok, konsumsi alkohol jugadapat memicu tekanan darah tinggi (Ibrahim, 2016).

Mengubah pola hidup/intervensi nonfarmakologis pada penderita hipertensi lanjut usia, sangat dianjurkan untuk menurunkan tekanan darah diantaranya menurunkan berat badan, menghentikan minum alkohol, mengurangi asupan garam, berhenti merokok, selain itu hipertensi dapat dicegah dengan melakukan senam lansia. Senam lansia sangat penting peranannya 
terutama bagi lansia, dengan melakukan senam lansia maka lansia tersebut dapat mempertahankan bahkan meningkatkan derajat kesehatannya. Senam Lansia adalah olahraga yang berunsur memadukan gerak untuk memacu kekuatan otot, peregangan untuk meningkatkan kelenturan badan dan kontraksi otot-otot badan, dengan melakukan senam lansia maka dapat menurunkan tekanan darah (Stanley, 2010).

Berdasarkan letar belakang di atas penelitian ini bertujuanh untuk mendeskripsikan perubahan tekanan darah pada lansia hipertensi yang melakukan senam lansia.

\section{Metode}

Penelitian ini menggunakan desain penelitian deskriptif studi kasus. Populasi yang digunakan adalah penderita hipertensi yang mengikuti mengikuti senam lansia di UPT Puskesmas Ngantang Kabupaten
Malang dan memenuhi kriteria yaitu: berusia minimal 60 tahun, telah didiagnosis menderita hipertensi derajat 1 atau 2, tidak mengalami cedera/kelemahan fisik dan tedak mengkonsumsi obat hipertensi sebelum senam. Berdasaran kriteria tersebut didapatkan sebanyak 20 orang pasien dengan teknik purposive sampling.

Partisipan/lansia hipertensi melakukan senam lansia dengan frekuensi latihan 2 kali/minggu, durasi 45 menit selama 4 minggu. Pengumpulan data dilakukan dengan menggunakan observasi, wawancara dan studi dokumentasi. Data dianalisis dan disajikan secara deskriptif dengan tabel.

\section{Hasil}

Secara umum gambaran pasien hipertensi dan perubahan tekanan darah setelah melakukan senam lansia dapat dilihat dalam tabel di bawah.

Tabel 1. Karakteristik Subyek Berdasarkan Usia di UPT Puskesmas Ngantang Kabupaten Malang Tahun 2019 (n=20).

\begin{tabular}{llcc} 
No. & Kategori & Frekuensi & Presentase \\
1 & $60-65$ tahun & 10 & $50 \%$ \\
\hline 2 & $66-70$ tahun & 6 & $30 \%$ \\
\hline 3 & $71-75$ tahun & 3 & $15 \%$ \\
\hline 4 & $76-80$ tahun & 1 & $5 \%$ \\
\hline Jumlah & & 20 & $100 \%$ \\
\hline
\end{tabular}

Tabel 2. Karakteristik Subyek Berdasarkan Jenis Kelamin di UPT Puskesmas Ngantang Kabupaten Malang Tahun $2019(\mathrm{n}=\mathbf{2 0})$.

\begin{tabular}{llcc}
\hline No. & Kategori & Frekuensi & Presentase \\
\hline 1 & Perempuan & 11 & $55 \%$ \\
\hline
\end{tabular}




\begin{tabular}{lccc}
\hline 2 & Laki-laki & 9 & $45 \%$ \\
\hline Jumlah & 20 & $100 \%$ \\
\hline
\end{tabular}

Tabel 3. Karakteristik Subyek Berdasarkan Pendidikan di UPT Puskesmas Ngantang Kabupaten Malang Tahun 2019 (n=20).

\begin{tabular}{clcc}
\hline No. & Kategori & Frekuensi & Presentase \\
\hline 1 & Tidak tamat SD & 5 & 25 \\
\hline 2 & SD & 8 & 40 \\
\hline 3 & SMP & 4 & 20 \\
\hline 4 & SMA & 3 & 15 \\
\hline Jumlah & 20 & $100 \%$ \\
\hline
\end{tabular}

Tabel 4. Karakteristik Subyek Berdasarkan Pekerjaan di UPT Puskesmas Ngantang Kabupaten Malang Tahun $2019(n=20)$.

\begin{tabular}{clcc}
\hline No. & Kategori & Frekuensi & Presentase \\
\hline 1 & Petani & 10 & 50 \\
\hline 2 & Pedagang & 6 & 30 \\
\hline 3 & Tidak Bekerja & 4 & 20 \\
\hline Jumlah & & 20 & $100 \%$ \\
\hline
\end{tabular}

Tabel 5. Distribusi Frekuensi Subyek Berdasarkan Lama Hipertensi di UPT Puskesmas Ngantang Kabupaten Malang Tahun 2019 (n=20).

\begin{tabular}{clcc} 
No. & Kategori & Frekuensi & Presentase \\
\hline 1 & 1-2 Tahun & 9 & 45 \\
\hline 2 & 3-4 Tahun & 10 & 50 \\
\hline 3 & $>5$ Tahun & 1 & 5 \\
\hline Jumlah & & 20 & $100 \%$ \\
\hline
\end{tabular}

Tabel 6. Distribusi Frekuensi Subyek Berdasarkan Riwayat Hipertensi Keluarga di UPT Puskesmas Ngantang Kabupaten Malang Tahun 2019 (n=20)

\begin{tabular}{clcc}
\hline No. & Kategori & Frekuensi & Presentase \\
\hline 1 & Ada & 13 & 65 \\
\hline 2 & Tidak Ada & 7 & 35 \\
\hline Jumlah & & 20 & $100 \%$ \\
\hline
\end{tabular}

Tabel 7. Distribusi Frekuensi Penyakit Subyek selain Hipertensi di UPT Puskesmas Ngantang Kabupaten Malang Tahun 2019 (n=20).

\begin{tabular}{clcc} 
No. & Kategori & Frekuensi & Presentase \\
\hline 1 & Diabetes & 3 & 15 \\
\hline 2 & Osteoporosis & 3 & 15 \\
\hline 3 & Tidak Ada & 14 & 70 \\
\hline Jumlah & 20 & $100 \%$ \\
\hline
\end{tabular}


Tabel 8 Distribusi Frekuensi Tekanan Darah Subyek Sebelum Melakukan Senam Lansia di UPT Puskesmas Ngantang Kabupaten Malang Tahun 2019 (n=20).

\begin{tabular}{cccc}
\hline No. & Kategori & Frekuensi & Presentase \\
\hline 1 & Derajat I & 11 & 55 \\
\hline 2 & Derajat II & 9 & 45 \\
\hline Jumlah & 20 & $100 \%$ \\
\hline
\end{tabular}

Tabel 9 Distribusi Frekuensi Tekanan Darah Subyek Setelah Melakukan Senam Lansia di UPT Puskesmas Ngantang Kabupaten Malang Tahun 2019 (n=20).

\begin{tabular}{clcc} 
No. & Kategori & Frekuensi & Presentase \\
\hline 1 & Prahipertensi & 3 & 15 \\
\hline 2 & Derajat I & 15 & 75 \\
\hline 3 & Derajat II & 2 & 10 \\
\hline Jumlah & & 20 & $100 \%$ \\
\hline
\end{tabular}

Tabel 10 Distribusi Frekuensi Perubahan Tekanan Darah Sesudah Melakukan Senam Lansiadi UPT Puskesmas Ngantang Kabupaten Malang Tahun 2019 (n=20).

\begin{tabular}{clcc} 
No. & Kategori & Frekuensi & Presentase \\
\hline 1 & Naik & 1 & 5 \\
\hline 2 & Turun & 18 & 90 \\
\hline 3 & Tetap & 1 & 5 \\
\hline Jumlah & & 20 & $100 \%$ \\
\hline
\end{tabular}

\section{Pembahasan}

Berdasarkan hasil penelitian yang mempengaruhi terjadinya hipertensi didapatkan bahwa sebelum melakukan diantaranya umur. Pada penelitian ini senam lansia sebagian besar pasien diketahui bahwa seluruh subyek berusia di mempunyai tekanan darah dengan hipertensi derajat I (140-159/90-99 $\mathrm{mmHg})$ yaitu sebanyak 11 orang (55\%), dan hipertensi derajat II $(\geq 160 / \geq 100)$ sebanyak 9 orang (45\%). Hasil tersebut menunjukkan bahwa sebagian besar lansia di Puskesmas Ngantang Kabupaten Malang menderita hipertensi dengan derajat I. Salah satu faktor atas 60 tahun. Pada usia ini pada umumnya seseorang mempunyai risiko tinggi untuk menderita berbagai macam penyakit degeneratif diantaranya penyakit hipertensi.

Hal ini sesuai pendapat Bustan (2010), menyatakan bahwa semakin tinggi umur seseorang semakin tinggi tekanan darahnya, jadi orang yang lebih tua cenderung 
mempunyai tekanan darah yang tinggi dari orang yang berusia lebih muda. Begitu juga menurut Depkes (2012), tingginya hipertensi sejalan dengan bertambahnya umur, disebabkan oleh perubahan struktur pada pembuluh besar sehingga lumen menjadi sempit dan dinding pembuluh darah menjadi lebih kaku, sebagai akibat adalah meningkatnya tekanan darah sistolik.

Peneliti berpendapat bahwa penyakit hipertensi pada lansia terkait dengan usia, semakin tua usia seseorang membuat hilangnya elastisitas jaringan ikat dan penurunan dalam relaksasi otot polos pembuluh darah yang pada gilirannya menurunkan kemampuan daya regang pembuluh darah. Konsekuensinya aorta dan arteri besar berkurang kemampuannya dalam mengakomodasi volume darah yang dipompa oleh jantung mengakibatkan penurunan curah jantung dan peningkatan tahanan perifer. Sehingga umur merupakan faktor risiko yang tidak dapat dihindari dan memiliki hubungan yang positif terhadap hipertensi. Oleh sebab itu yang perlu dilakukan yaitu menjaga ketahanan fisik, mengurangi perilaku berisiko seperti merokok, begadang, minum kopi, alkohol dan perilaku berisiko lainnya yang biasa dilakukan.

Jenis kelamin juga merupakan salah satu faktor yang dapat mempengaruhi kejadian hipertensi. Pada hasil penelitian diketahui bahwa jenis kelamin subyekterbanyak perempuan sebagaimana yang ditunjukkan pada tabel 4.2 yaitu subyek yang mengalami hipertensi berjenis kelamin perempuan sebanyak 9 orang $(55 \%)$ dan berjenis kelamin laki-laki sebanyak 9 orang $(45 \%)$. Hal ini terkait dengan penurunan hormon estrogen, sehingga kemampuan tubuh untuk melindungi dari zat radika bebas juga menurun.

Hal ini sesuai Bustan (2010) juga menyatakan bahwa lebih dari setengah penderita hipertensi pada lansia berjenis kelamin perempuan yaitu sekitar 56,5\% . Hipertensi lebih banyak terjadi pada pria bila terjadi pada usia dewasa muda. Tetapi lebih banyak menyerang wanita setelah umur 55 tahun, sekitar $60 \%$ penderita hipertensi adalah wanita. Penyakit hipertensi pada lansia perempuan dikarenakan pada perempuan meningkat seiring dengan bertambahnya usia yang mana pada perempuan masa premenopause cenderung memiliki tekanan darah lebih tinggi daripada laki-laki penyebabnya wanita mulai kehilangan sedikit demi sedikit hormon estrogen yang selama ini melindungi pembuluh darah dari kerusakan.

Proses ini terus berlanjut dimana hormon estrogen tersebut berubah kuantitasnya sesuai dengan umur wanita secara alami, yang umumnya mulai terjadi pada wanita umur 45-55 tahun. Dengan 
demikian dapat disimpulkan bahwa kelompok lansia yang berumur 60 tahun keatas dapat meningkatkan resiko hipertensi. Ini disebabkan adanya perubahan alami pada jantung, pembuluh darah, dan hormon.

Hipertensi juga dapat dipengaruhi oleh adanya faktor genetic. Pada penelitian ini sebagian besar subyek yang mengalami hipertensi mempunyai riwayat keluargamenderita hipertensi yaitu sebanyak 13 orang (65\%). Data ini menunjukkan bahwa tingginya kejadian hipertensi pada lansia di tempat penelitian ini karena sebagian besar ada riwayat keluarga yang menderita hipertensi, karena pada keluarga tertentu ada yang menderita hipertensi akan menyebabkan keluarga itu mempunyai risiko menderita hipertensi.

Hal ini menurut Bustan (2010) menyatakan bahwa adanya faktor genetik pada keluarga tertentu akan menyebabkan keluarga itu mempunyai risiko menderita hipertensi. Hal ini berhubungan dengan peningkatan kadar sodium intraseluler dan rendahnya rasio antara potasium terhadap sodium. Selain itu didapatkan $70-80 \%$ kasus hipertensi esensial dengan riwayat hipertensi dalam keluarga. Seseorang akan memiliki kemungkinan lebih besar untuk mendapatkan hipertensi jika orang tuanya adalah penderita hipertensi.

Menurut peneliti tingginya kejadian hipertensi pada lansia pada penelitian ini disebabkan karena adanya riwayat keluara yang sebagian besar pernah menderita hipertensi, sehingga bagi seseorang yang ada pihak keluarga menderita hipertensi maka kemungkinan besar akan menurun pada anggota keluarga yang lain hal ini berhubungan dengan genetik.

Berdasarkan hasil penelitian pada subyek sesudah melakukan senam lansia didapatkan bahwa tekanan darah kategori hipertensi derajat I (140-159/90-99 mmHg) sebanyak 15 orang (75\%), prahipertensi (120-139/80-89) sebanyak 3orang (15\%) dan hipertensi derajat II $(\geq 160 / \geq 100)$ sebanyak 2 orang (10\%). Dari data tersebut menunjukkan bahwa sebagian besar subyeksesudah melakukan senam lansia mempunyai tekanan darah turun sebanyak 18 orang (90\%), tekanan darah naik sebanyak 1 orang (5\%) dan tekanan darah tetap sebanyak 1 orang (5\%). Hasil tersebut menunjukkan bahwa senam lansia dapat menurunkan tekanan darah pada lansia hipertensi. Nilai tekanan darah sesudah melakukan senam lansia pada lansia umumnya lebih rendah atau terjadi penurunan dari sebelum melakukan senam lansiadengan kisaran 140/80 mmHg. Hal ini sesuai hasil penelitian Stanley (2010) menyatakan bahwa senam lansia sangat penting peranannya terutama bagi lansia, dengan melakukan senam lansia maka lansia tersebut dapat mempertahankan bahkan meningkatkan derajat kesehatannya. Senam 
Lansia adalah olahraga yang berunsur memadukan gerak untuk memacu kekuatan otot, peregangan untuk meningkatkan kelenturan badan dan kontraksi otot-otot badan, dengan melakukan senam lansia maka dapat menurunkan tekanan darah. Menurut peneliti adanya penurunan tekanan darah pada lansia hipertensi sesudah melakukan senam lansia adalah karena berkurangnya hambatan atau tahanan dalam kapiler darah sehingga darah dapat mengalir dengan mudah dan lancar dibandingkan dengan sebelum melakukan senam lansia. Senam lansia juga membantu meningkatkan kebugaran dan fitalitas tubuh lansia dalam mempertahankan kesehatannya. Senam lansia bermanfaat bagi kesehatan salah satunya menurunkan tekanan darah bagi lansia yang menderita hipertensi. Senam lansia akan membuat seseorang lebih kuat menghadapi stres dan gangguan hidup sehari-hari, lebih dapat berkonsentrasi, tidur lebih nyenyak. Hal ini disebabkan karena gerakan fisik bisa digunakan untuk memproyeksikan ketegangan, sehingga setelah latihan, orang merasa ada beban jiwa yang terbebaskan. Senam lansia akan membantu tubuh lanjut usia agar tetap bugar dan segar, karena senam ini mampu melatih tulang tetap kuat, mendorong jantung bekerja secara optimal dan membantu menghilangkan radikal bebas yang berkeliaran didalam tubuh.
Senam lansia dapat mengurangi tekanan darah bukan hanya disebabkan berkurangnya berat badan, tetapi juga disebabkan bagaimana tekanan darah tersebut dihasilkan. Tekanan darah ditentukan oleh dua hal yaitu jumlah darah yang dipompakan jantung perdetik dan hambatan yang dihadapi darah dalam melakukan tugasnya melalui arteri. Pada fisik yang senantiasa aktif pembuluh darah lebih elastis sehingga mengurangi tahanan diperifer. Senam lansia dapat menyebabkan pertumbuhan pembuluh darah kapiler yang baru dan jalan darah yang baru. Dengan demikian hal yang menghambat pengaliran darah dapat dihindarkan atau dikurangi yang berarti menurunkan tekanan darah. Dengan demikian dapat disimpulkan bahwa untuk mengurangi meningkatnya tekanan darah pada lansia dan keluarga agar mulai melakukan senam lansia secara baik dan benar. Hasil penelitian ini juga menemukan masih adannya subyek yang tidak mengalami penurunan tekanan darah setelah melakukan senam lansia yaitu sebanyak 1 subyek (5\%) dan mengalami kenaikan tekanan darah sebanyak 1 subyek (5\%). Menurut peneliti berdasarkan fakta bahwa masih ada subyek yang tidak mengalami penurunan tekanan darah dan mengalami kenaikan tekanan darah, hal ini kemungkinan besar karena subyek tersebut tidak melakukan senam lansia secara benar 
dan teratur dibanding dengan lansia yang tekanan darahnya mengalami penurunan, sehingga menyebabkan tidak ada perubahan tekanan darahnya.

\section{Kesimpulan Dan Saran}

\section{Kesimpulan}

Berdasarkan hasil penelitian didapatkan bahwa lansia hipertensi yang sebelum melakukan program senam lansia mempunyai tekanan darah kategori hipertensi derajat I (140-159/90-99 $\mathrm{mmHg})$ sebanyak 11 orang (55\%), dan hipertensi derajat II $(\geq 160 / \geq 100)$ sebanyak 9 orang (45\%). Namun sesudah melakukan program senam lansia sebagian besar turun sebanyak 18 orang (90\%). Hal ini menunjukkan bahwa dengan melakukan senam senam lansia dapat membantu menurunkan tekanan darah bagi lansia yang menderita hipertensi.

\section{Saran}

Saran bagi lansia penderita hipertensi diharapkan dapat melakukan senam lansia secara rutin, baik dan benar untuk menunjang program terapi selain farmakologis serta dapat melakukan pemeriksaan tekanan darah secara rutin di pelayanan kesehatan. Bagi institusi pelayanan kesehatan khususnya Puskesmas dapat tetap mempertahankan dan meningkatkan program senam lansia secara rutin, dan bagi peneliti selanjutnya diharapkan hasil penelitian ini dapat menjadi acuan untuk pengembangan penelitian dengan desain dan metode yang lebih baik untuk mengidentifikasi efektifitas senam lansia terhadar penurunan tekanan darah pada penderita hipertensi.

\section{Referensi}

Azizah. (2011). Keperawatan Lanjut Usia. Yogyakarta: Graha Ilmu.

Bustan. (2010). Epidemiologi Penyakit Tidak Menular. cet.2. Jakarta.Rineka Cipta

Darmojo, B. (2012). Buku Ajar Geriatri Ilmu Kesehatan Usia Lanjut. Jakarta. FKUI

Depkes RI. (2010). Pedoman Pembinaan Kesehatan Usia Lanjut Bagi Petugas Kesehatan. Jakarta : Depkes RI

Dinkes Jatim. (2014). Profil Kesehatan Provinsi Jawa Timur. Surabaya: Dinkes Jawa Timur.

Dinkes Jatim. (2016). Profil Kesehatan Provinsi Jawa Timur Tahun 2016. Dinas Kesehatan Jawa Timur.

Ibrahim. (2016). Asuhan Keperawatan pada Lansia dengan Hipertensi. Idea Nursing Journal ISSN 2087-2879. Bagian Keilmuan dan Keperawatan Jiwa dan Komunitas, PSIK-FK Universitas Syiah Kuala.

Kemenkes RI. (2016). Situasi Lanjut Usia di Indonesia. Pusat Data dan 
Informasi Kementerian Kesehatan RI.

Kuswardhani. (2011). Penatalaksanaan

Hipertensi Pada Lanjut Usia.

Jurnal. Denpasar: Bagian Penyakit

Dalam FK. Universitas Udayana.

Maryam. (2012). Mengenal Usia Lanjut Dan

Perawatannya. Jakarta. Salemba Medika

Mufidah dkk, (2012). Peningkatan Stabilitas Postural Pada Lansia Melalui Balance Exercise. Jurnal. Surabaya. FK Unair
Murwani. (2014). Perawatan Pasien Penyakit Dalam. Yogyakarta: Mitra Cendika

Notoatmodjo, S. (2010). Metode Penelitian Kesehatan. Jakarta. Rineka Cipta.

Nugroho, W. (2010). Keperawatan Gerontik \& Geriatrik. Edisi 3. Jakarta: EGC. Nursalam. (2010). Konsep dan Penerapan Metodologi Penelitian Ilmu Keperawatan. Jakarta : Salemba Medika.

Puskesmas Ngantang. (2017). Data Rekam Medis Laporan Lansia di Puskemas Ngantang 2017. 